\title{
Diversity of marine bacteria producing beta-glucosidase inhibitors
}

\author{
Sony Pandey ${ }^{*}$, Ayinampudi Sree, Soumya Suchismita Dash, Dipti Priya Sethi and Lipsa Chowdhury
}

\begin{abstract}
Background: Beta-glucosidase inhibitors are being extensively studied for use as anti-diabetics, anti-obesity and anti-tumour compounds. So far, these compounds have been reported in large numbers from plants, mushrooms, algae and fungi. There are very few reports of such inhibitors from bacteria in the open literature, particularly marine bacteria; although the best known inhibitor deoxynojirimycin was isolated from bacilli and actinomycete. Through this study, we tried to discover the diversity of microbial associates of marine sponge and sediment producing $\beta$-glucosidase inhibitors.

Results: We found 41 (22.7\%) out of 181 bacteria, produced such inhibitors. The inhibitors are abundant in bacterial associates of marine sponge Aka coralliphaga. When these bacteria were phylogenetically analyzed, it was found that marine bacteria producing glucosidase inhibitors belong to the phylum Firmicutes (23), Actinobacteria (9), Proteobacteria (7) and Bacteroidetes (1).

Conclusion: A significant number of marine bacteria belonging to a wide range of bacterial taxa were found to produce $\beta$-glucosidase inhibitors. These compounds are abundantly present in bacteria of the phylum Firmicutes followed by the phylum Actinobacteria. The results nurture a hope of finding new compounds, which can inhibit glucosidases, in the bacterial domain of marine organisms. Thus, marine microbial cells can be utilized as producers of pharmacologically essential enzyme inhibitors.
\end{abstract}

Keywords: Glucosidase inhibitor, Diversity, Microbial extracts, Phyla, Marine microorganisms, Anti-diabetics, Anti-obesity, Marine sponge, Aka coralliphaga, Sarcotragus fasciculatus

\section{Background}

Glucosidase inhibitors are emerging as important therapeutic agents since they interfere with crucial metabolic functions in biological systems, and have widespread applications in pharmacology and agriculture. They also provide useful insights into the role of glucosidase in living systems and enzyme action mechanism. Their therapeutic applications alone range from the treatment of infections, to metabolic and genetic disorders like - viral infections of HIV/Influenza, metastatic cancer, diabetes, obesity and lysosomal storage diseases [1]. At present nojirimycin and its derivatives are being extensively used as $\beta$-glucosidase inhibitors. Some species of Streptomyces and Bacillus produce antimicrobial compounds like validamycin and nojirimycin, which showed $\beta$-glucosidase inhibition later on [2-4]. Yet the search for $\beta$-glucosidase

\footnotetext{
* Correspondence: sony@immt.res.in

Environment and Sustainability Department, CSIR - Institute of Minerals and Materials Technology, Bhubaneswar, Odisha 751013, India
}

inhibitors in microorganisms is very much limited, though natural sources like plant extracts, microalgae, cyanobacteria and mushrooms have been explored [5-8].

The natural compounds exhibiting $\beta$-glucosidase inhibition belong to a variety of chemical classes like disaccharides, iminosugars, carbasugars, thiosugars and non-sugar derivatives [9]. There are naturally occurring sugar mimics in the plant and microbial world which have the potential to act as $\beta$-glucosidase inhibitors, since they are structural analogues of natural sugar substrates [10]. Beta-glucosidase inhibitors exhibit a range of structure and functions in nature, so it is intriguing to search for these inhibitors in natural resources, which have the potential to produce different structures. Marine microflora is one such natural resource which remains to be explored for the presence of $\beta$-glucosidase inhibitors. Microbes living in the marine environment survive under extreme conditions of temperature, pressure and nutritional competition; and hence they possess 
metabolic capabilities, which may be different from their terrestrial counterparts. The inhibitors of $\beta$-glucosidases are expected to be diverse in the marine environment since this enzyme is widespread and diverse [11]. In the past few decades, marine microbes from the sponges and sediment have given several novel therapeutic molecules [12]. However, except for a report by Imada and Okami 1995 [13], on a deep-sea actinomycete isolate producing $\beta$-glucosidase inhibitor, we did not find any literature in this area. This prompted us to seek $\beta$ glucosidase inhibitors in marine sponge and sediment associated bacteria.

When we investigated the microbial associates of sponges and sediments using our new method of $\beta$-glucosidase inhibition assay, we found $\beta$-glucosidase inhibitors in several marine microbial extracts [14]. Many authors have emphasized that phylogenetic diversity is the source of varied biological activity [15-17]. Thus, the objective of this study was to find the taxonomic groups of bacteria, isolated from marine sponges and sediment samples, involved in the inhibition activity. To the best of our knowledge, this report is the first to point out the phylogenetic diversity of marine microbes producing $\beta$-glucosidase inhibitors.

\section{Results and discussion}

Glucosidases catalyze the cleavage of glycosidic bonds involving $\alpha$ - and $\beta$-linked glucose units or the bonds between sugars and a non-carbohydrate aglycone moiety. Beta-glucosidases play a crucial role in several biochemical processes like degradation of polysaccharides, lysosomal glycoconjugate catabolism, glycoprotein and glycolipid processing. Glucosidase inhibitors have become the subject of intense scrutiny since the isolation of deoxynojirimycin in 1966, because of their profound effect on glycoprotein processing, oligosaccharide metabolism, cellcell and cell-virus recognition processes $[18,19]$. Our aim was to find the diversity of marine bacteria producing $\beta$-glucosidase inhibitors in response to the presence of this enzyme in their environment, and we indeed found highly diverse microbial population possessing the ability to produce these enzyme inhibitors.

Out of the 181 isolates tested 41 (22.7\%) organisms showed $\beta$-glucosidase inhibition potential; of these 41 isolates, 27 belonged to sediment samples, 6 and 8 respectively from the sponge Sarcotragus fasciculatus and Aka coralliphaga of Bay of Bengal. Table 1 presents quantitative data on the number of samples screened, beta-glucosidase inhibiting organisms and their diversity at phyla level. Our results show that $22.7 \%$ of the microorganisms screened are able to inhibit $\beta$-glucosidase, which further strengthens the belief that glucosidase inhibitors are widespread in the plant and microbial world [10]. Twenty seven (24.5\%) out of 110 isolates from sediment samples were positive for beta-glucosidase, 6 out of the 41 (14.6\%) isolates from the sponge Sarcotragus fasciculatus and 8 out of 30 (26.6\%) from the sponge Aka coralliphaga produced the inhibitors. Since long, the marine sponge associated microbes have been projected as a prolific source of bioactive compounds

Table 1 Data on screening results

\begin{tabular}{|c|c|c|c|c|c|}
\hline Sample & $\begin{array}{l}\text { No. of isolates } \\
\text { screened }\end{array}$ & $\begin{array}{l}\text { No. of isolates } \\
\text { positive }\end{array}$ & $\begin{array}{l}\text { No. of different } \\
\text { species obtained* }\end{array}$ & $\begin{array}{l}\text { No. of genus } \\
\text { obtained }\end{array}$ & $\begin{array}{l}\text { No. of different phyla } \\
\text { obtained }\end{array}$ \\
\hline \multirow[t]{4}{*}{ SD1 Sediment } & 27 & 11 & $7(2)$ & 9 & Firmicutes - 3 \\
\hline & & & & & Actinobacteria - 4 \\
\hline & & & & & Proteobacteria - 3 \\
\hline & & & & & Bacteroidetes - 1 \\
\hline \multirow[t]{3}{*}{ SD2 Sediment } & 30 & 13 & $9(2)$ & 5 & Firmicutes - 10 \\
\hline & & & & & Actinobacteria - 2 \\
\hline & & & & & Proteobacteria - 1 \\
\hline \multirow[t]{3}{*}{ GD Sediment } & 53 & 3 & $2(1)$ & 3 & Firmicutes - 1 \\
\hline & & & & & Actinobacteria - 1 \\
\hline & & & & & Proteobacteria - 1 \\
\hline \multirow[t]{2}{*}{ Sponge Sarcotragus fasciculatus } & 41 & 6 & $3(1)$ & 3 & Firmicutes - 5 \\
\hline & & & & & Proteobacteria - 1 \\
\hline \multirow[t]{3}{*}{ Sponge Aka coralliphaga } & 30 & 8 & $7(1)$ & 5 & Firmicutes - 5 \\
\hline & & & & & Actinobacteria - 2 \\
\hline & & & & & Proteobacteria - 1 \\
\hline Total & 181 & 41 & $26^{\wedge}$ & $19^{\wedge}$ & \\
\hline
\end{tabular}

${ }^{*}$ Number in brackets are unidentified at species level.

${ }^{\wedge}$ The numbers exclude overlapping genus and species obtained in different samples. 
Table $2 \boldsymbol{\beta}$-Glucosidase inhibition activity and identity of the marine isolates

\begin{tabular}{|c|c|c|c|c|c|}
\hline SI. No. & Strain & $\begin{array}{c}\beta \text {-Glucosidase } \\
\text { inhibition (in } \mathrm{mm}^{*} \text { ) }\end{array}$ & Identity (\%) & Closest match & $\begin{array}{c}\text { GenBank accession } \\
\text { number }\end{array}$ \\
\hline 1 & SD1-1 & 4 & 99.8 & Stenotrophomonas rhizophila & JQ359448 \\
\hline 2 & SD1-3 & 4 & 100 & Arthrobacter koreensis & JQ409500 \\
\hline 3 & SD1-6(1) & 5 & 99.0 & Advenella kashmirensis & JQ359449 \\
\hline 4 & SD1-8 & 5 & 99.7 & Microbacterium oleivorans & JQ359450 \\
\hline 5 & SD1-13 & 4 & 100 & Arthrobacter koreensis & $J Q 409501$ \\
\hline 6 & SD1-14(1) & 6 & 99.8 & Planomicrobium okeanokoites & JQ409502 \\
\hline 7 & SD1-17 & 4 & 97.3 & Dietzia maris & JQ409503 \\
\hline 8 & SD1-18 & 4 & 96.0 & Chryseomicrobium sp. & JQ409504 \\
\hline 9 & SD1-20(1) & 4 & 90.0 & Sphingobacterium sp. & JQ409505 \\
\hline 10 & SD1-23 & 4 & 97.3 & Exiguobacterium marinum & JQ409506 \\
\hline 11 & SD1-25 & 4 & 98.5 & Stenotrophomonas rhizophila & JQ409507 \\
\hline 12 & SD2-1 & 4 & 100 & Bacillus flexus & JQ409508 \\
\hline 13 & SD2-2(1) & 5 & 99.5 & Bacillus oceanisediminis & JQ409509 \\
\hline 14 & SD2-2(2) & 5 & 100 & Bacillus siamensis & JQ409510 \\
\hline 15 & SD2-3(2) & 6 & 100 & Bacillus flexus & JQ409511 \\
\hline 16 & SD2-5 & 4 & 100 & Bacillus sp. & - \\
\hline 17 & SD2-6(1) & 5 & 100 & Arthrobacter koreensis & JQ409512 \\
\hline 18 & SD2-7(2) & 5 & 100 & Bacillus stratosphericus & $J Q 409513$ \\
\hline 19 & SD2-15(1) & 4 & 91.0 & Exiguobacterium sp. & JQ409514 \\
\hline 20 & SD2-17 & 4 & 99.1 & Bacillus oceanisediminis & JQ409515 \\
\hline 21 & SD2-18 & 4 & 99.8 & Microbacterium esteraromaticum & JQ409516 \\
\hline 22 & SD2-20 & 4 & 98.7 & Bacillus methylotrophicus & JQ409517 \\
\hline 23 & SD2-22 & 5 & 99.8 & Bacillus subtilis subsp. inaquosorum & JQ409518 \\
\hline 24 & SD2-24 & 4 & 99.7 & Psychrobacter maritimus & JQ409519 \\
\hline 25 & GDN4 & 5 & 99.6 & Vibrio communis & JQ409520 \\
\hline 26 & GDB16 & 5 & 95 & Bacillus sp. & JQ409521 \\
\hline 27 & GDA11 & 4 & 99.6 & Streptomyces coelicoflavus & JQ409522 \\
\hline 28 & GPB8 & 4 & 99.7 & Staphylococcus gallinarum & JQ409523 \\
\hline 29 & GPB9 & 4 & 99.7 & Bacillus subtilis subsp. spizizenii & JQ409524 \\
\hline 30 & GPB10 & 4 & 96.0 & Pseudochrobactrum sp. & JQ409525 \\
\hline 31 & GPB13 & 4 & 100 & Bacillus aryabhattai & JQ409526 \\
\hline 32 & GPB20 & 4 & 99.6 & Bacillus aryabhattai & JQ409527 \\
\hline 33 & GPB21 & 4 & 100 & Staphylococcus gallinarum & JQ409528 \\
\hline 34 & SP2B3 & 6 & 97.8 & Halomonas sulfidaeris & JQ409529 \\
\hline 35 & SP2B5 & 4 & 99.4 & Bacillus tequilensis & JQ409530 \\
\hline 36 & SP2B6 & 6 & 95.5 & Bacillus sp. & -- \\
\hline 37 & SP2B9 & 6 & 99.7 & Leucobacter chromiiresistens & JQ409531 \\
\hline 38 & SP2B11 & 5 & 98.8 & Planococcus rifitoensis & JQ409532 \\
\hline 39 & $\mathrm{SP} 2 \mathrm{~B} 12$ & 5 & 99.5 & Bacillus stratosphericus & JQ409533 \\
\hline 40 & SP2B20 & 6 & 100 & Bacillus amyloliquefaciens subsp. amyloliquefaciens & JQ409534 \\
\hline 41 & SP2A6 & 4 & 97.6 & Streptomyces rangoonensis & JQ409535 \\
\hline
\end{tabular}


[11]; our study shows that the sediment is also a good source of the inhibitor compound.

All the active isolates were identified by partial $16 \mathrm{~S}$ rDNA sequencing in the V1-V3 variable region and confirmed by culture characterization (data not shown). While Table 1 shows the quantitative data of the screening activity, Table 2 shows the qualitative data on the activity and identity of the positive isolates. The distribution of active isolates among different bacterial phyla is depicted in Figure 1. Based on the 16S rDNA sequence data, a phylogenetic tree was drawn (Figure 2).

An explanation to the observation of a wide range of microbial taxa involved in this activity could lie in the competitiveness of the ecosystem. In the ocean ecosystem, decomposable organic material is scarcely available so most of the heterotrophic bacteria in the ecosystem would secrete the glucosidase enzyme; and in order to compete with others for the small amount of nutrition, they would also secrete a variety of glucosidase inhibitors. The role of organic carbon availability is evident in the study by Liu et $a l$. 2008, where the $\beta$-glucosidase activity of mangrove sediments was compared with other water bodies including deep sea. The activity was found to be highest in the mangrove ecosystem due to the abundant availability of decomposable organic matter [23].

An interesting observation from this study is that very few Actinomycetes (21.9\%), contrary to their popular characteristic of bioactivity, have shown glucosidase inhibition as compared to Firmicutes bacteria (58.5\%) $[15,16]$. Observation of Table 2 shows glucosidase inhibition by species belonging to diverse genera; however only two species of Streptomyces were active. Six genera of Firmicutes bacteria - Planomicrobium, Chryseomicrobium, Exiguobacterium, Bacillus, Staphylococcus and Planococcus; and five genera of Actinobacteria - Leucobacter, Streptomyces, Microbacterium, Arthrobacter and

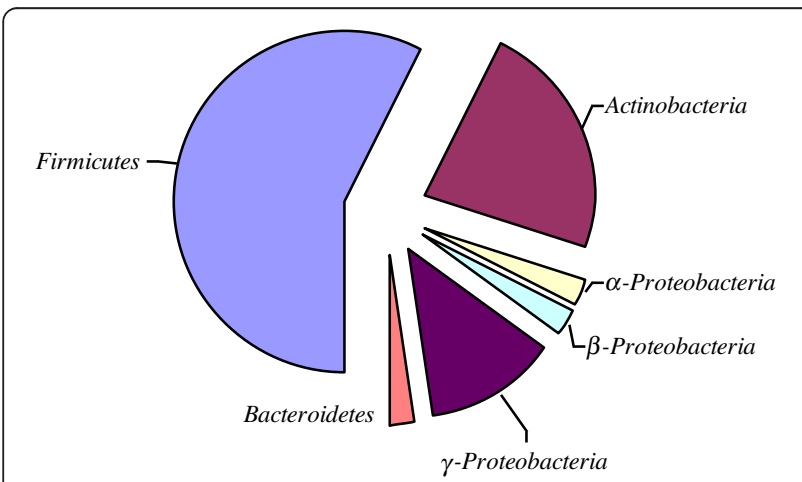

Figure 1 Distribution of $\beta$-glucosidase inhibiting marine isolates in different bacterial phyla showing Firmicutes making up the major fraction followed by Actinobacteria, Proteobacteria and Bacteroidetes. Within Proteobacteria, the $\gamma$-Proteobacteria constitutes the major fraction.
Dietzia, exhibited $\beta$-glucosidase inhibition. The bioactive isolates from sediment samples belonged to four phyla, whereas only three phyla were detected in the sponge samples (Table 1).

According to Stein et al. 1984, deoxynojirimycin has been isolated earlier from several species of Bacillus (phylum Firmicutes) and Streptomyces (phylum Actinobacteria) [4]. Even in our study majority of the active isolates belong to these phyla but, we report number of genera from these phyla to produce such natural compounds. Our finding is consistent with the general perception that, Firmicutes and Actinobacteria are better competitors in the natural environment since they are prolific producers of antibiotics and enzyme inhibitors.

A significant number of isolates - 7 out of 41 (17.1\%), belong to phylum Proteobacteria with representatives of all three classes $\alpha$-, $\beta$ - and $\gamma$-Proteobacteria. Species of Bacillus and Streptomyces are already known for their ability to produce diverse bioactive compounds; our finding is more important in the context of genera like Staphylococcus, Stenotrophomonas, Pseudochrobactrum, Advenella, Dietzia and Chryseomicrobium, which are hitherto unknown as producers of antimicrobial and antienzyme compounds. In fact, our study is the first to report glucosidase inhibition in many genera of bacteria, which have so far shown enzyme, cytotoxic, antimicrobial, antioxidant, biosurfactant and metal resistance properties only. Like, marine isolates of Planomicrobium, Planococcus, Microbacterium, Arthrobacter, Halomonas and Psychrobacter have shown weak cytotoxic activity earlier [24]. Enzymes like chitinase, xylanase, keratinase have been reported from Planococcus rifitoensis [25], Arthrobacter sp. [26] and Microbacterium sp. [27] respectively. Interestingly, Sphingobacterium has previously shown thioglucosidase activity [28] and recently $\alpha$-glucosidase has also been reported from a strain of Halomonas [29]. In fact, many Halomonas species are reported in literature with varied activity, for example, a marine derived Halomonas strain produced certain antimicrobial and cytotoxic compounds with the addition of anthranilic acid in the fermentation medium [30]. Our study is also the first to report very strong glucosidase inhibition activity in a chromium resistant species of Leucobacter from the sponge Aka coralliphaga. A number of other members from this genus have shown to have chromium tolerance and recently a species of Leucobacter has been reported to have potential biosurfactant activity [31,32].

Natural products from microbial associates of marine sponges and sediments are attractive because of the metabolic diversity they exhibit and scalability of the production process using biotechnological methods. Hence, the supply problem associated with marine invertebrates and plankton can be overcome [33]. Although the role of glucosidase inhibitors in marine sponge is not clear 


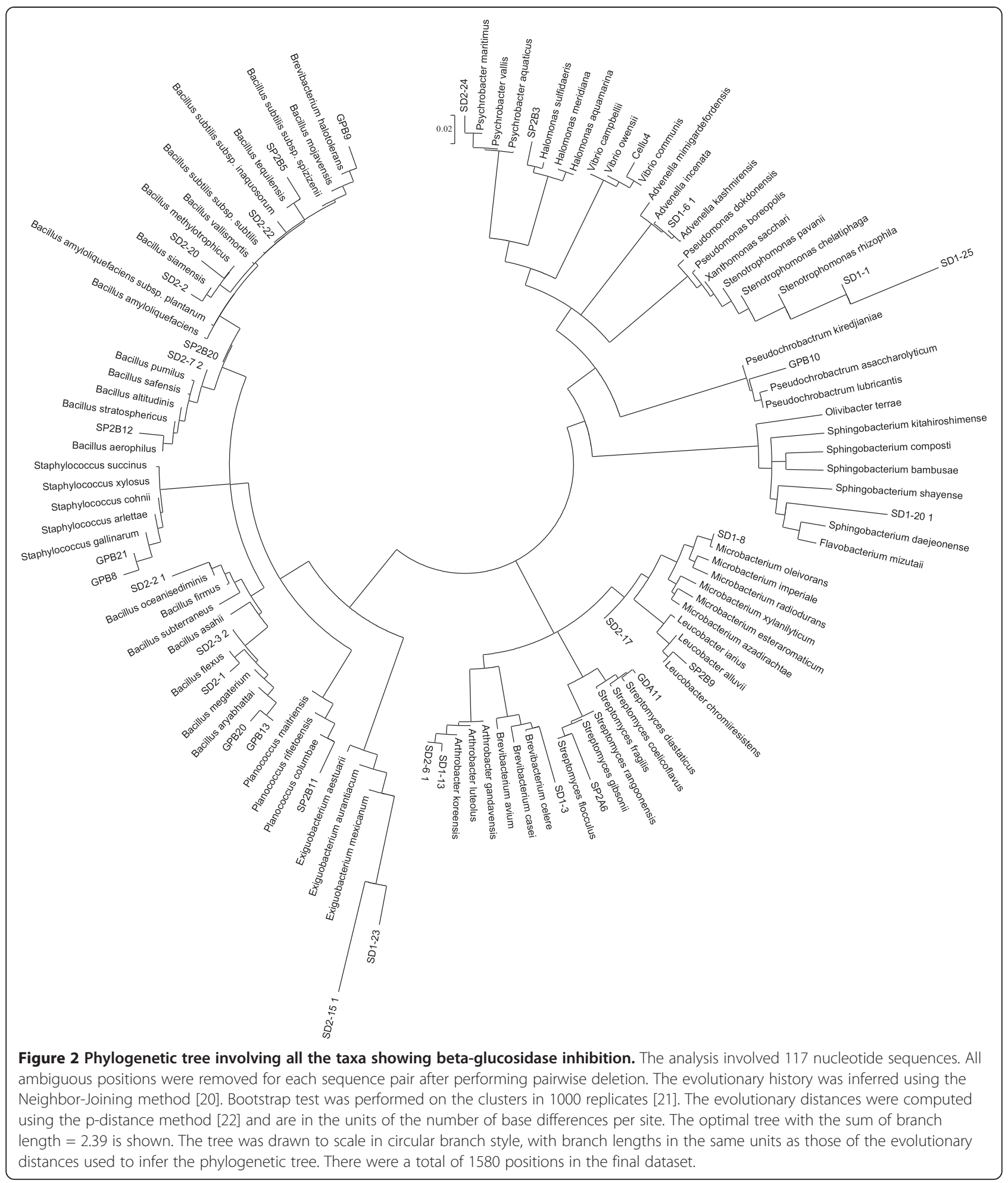

and further work is needed, we speculate that these extracellular inhibitors are released to prevent the other microbes from utilizing the carbohydrate carbon. We believe our revelations form only the tip of an iceberg, and there are many more cell factories hidden in the deep sea.

\section{Conclusion}

This study throws light on the microbial taxa which are hitherto not known for producing such compounds. Thus, within the realm of possibility we may assume these microorganisms have a potential to produce new glucosidase 
inhibitor compounds. Glucosidases are central to carbohydrate metabolism and efficient utilization of carbon sources determines the viability of microbes in any environment. In order to survive in competitive environments like the marine ecosystem, the microbial cells need to produce inhibitors against the glucosidases of other microbes. Sparse information is available on the glucosidase inhibition activity of the diverse microbial phyla found in the depths of ocean for comparison of our results. Probably the missing link between the phylogenetic diversity and functional diversity can be established, if all these inhibitors are structurally identified and their reaction mechanisms established.

\section{Methods}

\section{Bacterial strains and culture conditions}

A total of 181 marine microorganisms isolated from marine sediment (110), sponge Sarcotragus fasciculatus (41) and sponge Aka coralliphaga (30) were selected for this study, out of a collection of marine cultures isolated from the Bay of Bengal on the east coast of India. All the organisms grew on Nutrient Agar (Hi Media, Mumbai) media prepared in $50 \%$ aged natural seawater at $30^{\circ} \mathrm{C}$ within 48-72 hrs.

\section{Extraction of metabolites}

The marine cultures were grown in $50 \mathrm{ml}$ Nutrient Broth prepared in $50 \%$ natural seawater and incubated at $30^{\circ} \mathrm{C}$ in $200 \mathrm{rpm}$ shaker for $48 \mathrm{hrs}$. The cell biomass was centrifuged at $9000 \mathrm{rpm}$ for $20 \mathrm{~min}$, and the supernatant containing the secondary metabolites was collected in a $250 \mathrm{ml}$ flask; followed by mixing $10 \%$ diaion HP-20 (Sigma) and magnetic stirring for $30 \mathrm{~min}$. The contents of the flask were packed in a glass column, washed with $15 \mathrm{ml}$ distilled water, and eluted with $20 \mathrm{ml}$ methanol. The methanol fractions were evaporated in a rotary evaporator (Heidolph, Germany) and dissolved in DMSO, to make a final concentration of approx. $1 \mathrm{mg} / \mathrm{ml}$ and stored at $-20^{\circ} \mathrm{C}$.

\section{Beta-glucosidase inhibition assay}

The assay was performed as described by Pandey et $a l$. 2013 [14]. Briefly, $10 \mathrm{ml}$ enzyme agar solution was prepared with $0.7 \%$ agar powder dissolved at $80-100^{\circ} \mathrm{C}$ in $0.1 \mathrm{M}$ sodium acetate buffer, followed by the addition of $0.06 \% \mathrm{FeCl}_{3}$ and $0.01 \mathrm{U} / \mathrm{ml}$ enzyme $\beta$-glucosidase added at $60^{\circ} \mathrm{C}$, and the solution was poured into petri plates. Then $5 \mu \mathrm{l}$ of the samples were inoculated on the surface of the agar plate and incubated at room temperature for 15 min, followed by the addition of $0.2 \%$ esculin solution and again incubated at room temperature for $30 \mathrm{~min}$ for enzyme-substrate reaction. DMSO without extract was used as negative control, and the positive control was $0.75 \mu \mathrm{g}$ conduritol $\beta$-epoxide. The results were recorded by measuring the zone size. These experiments were repeated thrice with some extracts to check the reproducibility of results.

\section{Microbial identification}

All the cultures which showed a positive zone of inhibition were identified by morphological characterization and $16 \mathrm{~S}$ rRNA gene sequencing. DNA was isolated from the pure cultures by the method described by Pitcher et al., 1989 [34]. Purified genomic DNA was subjected to $16 \mathrm{~S}$ rRNA gene amplification using the universal primers $27 \mathrm{~F}$ and $1492 \mathrm{R}$ in a thermal Cycler (Eppendorf). The PCR amplification was performed in $25 \mu$ l reaction mixture containing 10 pmol of both the primers, 100150 ng DNA, 5 mM dNTPs, $1 X$ Taq polymerase buffer containing $15 \mathrm{mM} \mathrm{MgCl}_{2}$ and $0.5 \mu \mathrm{l}$ of Taq DNA polymerase (5 U/ $\mu \mathrm{l}$, Fermentas). The PCR programme was as follows: initial denaturation at $94^{\circ} \mathrm{C}$ for $5 \mathrm{~min}, 30$ cycles of $94^{\circ} \mathrm{C}$ for $1 \mathrm{~min}, 50^{\circ} \mathrm{C}$ for $1 \mathrm{~min}, 72^{\circ} \mathrm{C}$ for $2 \mathrm{~min}$ and final elongation at $72^{\circ} \mathrm{C}$ for $10 \mathrm{~min}$. The PCR product was separated on $1 \%$ agarose gel and the DNA fragments were extracted using Gel Extraction kit (Qiagen) as per the manufacturer's instructions. The purified $16 \mathrm{~S}$ rDNA was sequenced at Merck Biosciences, Bangalore and CSIR-IMMT in Beckman Coulter CEQ 8000 genetic analysis system. The sequences thus obtained were aligned with the GenBank sequences using BLAST program in NCBI (http://blast.ncbi.nlm.nih.gov) and the EzTaxon server 2.1 (http://147.47.212.35:8080/) [35], to obtain the closest matching type strain sequences from the database. The identity of the strain was established based on the sequence identity and corresponding morphological characters.

\section{Phylogenetic analysis}

The 16S rDNA sequences of the closest relatives of all the marine cultures showing positive glucosidase inhibition were retrieved from EzTaxon, and multiple sequence alignment was performed using Clustal_X program [36]. The evolutionary relatedness of all the strains was inferred using the Neighbor-Joining method, distance calculated using the p-distance method, followed by bootstrap test in 1000 replicates for each cluster and the phylogenetic tree was drawn in MEGA5.0 program available at http://www. megasoftware.net/ [37].

\section{Competing interests}

The authors declare no competing interests.

\section{Authors' contributions}

SP contributed to the experimental design, data acquisition, troubleshooting, analysis and interpretation of data, as well as drafting the manuscript. AS conceived the work, collected samples, and advised on the manuscript. SSD, DPD and LC helped in sample preparations and execution of work. All the authors have read and approved the final manuscript. 


\section{Acknowledgements}

The authors are thankful to Council of Scientific and Industrial Research for funding the work and Director CSIR-IMMT for the infrastructure support. We gratefully acknowledge Dr. Tapan Chakrabarti, former Head and founder of Microbial Type Culture Collection - an International Depository Authority, Chandigarh, India, for critically examining the manuscript.

Received: 6 March 2013 Accepted: 14 April 2013

Published: 17 April 2013

\section{References}

1. Asano N: Glycosidase inhibitors: updates and perspectives on practical use. Glycobiology 2003, 13:93R-104R.

2. Zhu YP, Yin LJ, Cheng YQ, Yamaki K, Mori Y, Su YC, Li LT: Effects of sources of carbon and nitrogen on production of a-glucosidase inhibitor by a newly isolated strain of Bacillus subtilis B2. Food Chem 2008, 109:737-742.

3. Schmidt DD, Frommer W, Muller L, Truscheit E: Glucosidase inhibitors from Bacilli. Naturwissenschaften 1979, 66:584-585.

4. Stein DC, Kopec LK, Yasbin RE, Young FE: Characterization of Bacillus subtilis DSM704 and its production of 1-Deoxynojirimycin. App/ Environ Microb 1984, 48:280-284

5. Ramkumar KM, Thayumanavan B, Palvannan T, Rajaguru P: Inhibitory effect of Gymnema Montanum leaves on a-glucosidase activity and a-amylase activity and their relationship with polyphenolic content. Med Chem Res 2009. doi:10.1007/s00044-009-9241-5.

6. Kim JH, Ryu YB, Kang NS, Lee BW, Heo JS, Jeong IY, Park KH: Glycosidase inhibitory Flavonoids from Sophora flavescens. Biol Pharm Bull 2006, 29:302-305.

7. Atsumi $\mathrm{S}$, Umezawa $\mathrm{K}$, linuma $\mathrm{H}$, Naganawa $H$, litaka $Y$, Takeuchi $T$ : Production, isolation and structure determination of a nove $\beta$-glucosiadse inhibitor cyclophellitol, from Phellinus sp. J Antibiot 1990, 43:49-53.

8. Cannell RJP, Kellam SJ, Owsianka AM, Walker JM: Microalgae and cyanobacteria as a source of glycosidase inhibitors. J Gen Microbio/ 1987 133:1701-1705.

9. de Melo EB, Gomes AS, Carvalho I: $\boldsymbol{\alpha}$ - and $\beta$-Glucosidase inhibitors: chemical structure and biological activity. Tetrahedron 2006, 62:10277-10302.

10. Asano N, Nash RJ, Molyneux RJ, Fleet GWJ: Sugar-mimic glycosidase inhibitors: natural occurrence, biological activity and prospects for therapeutic application. Tetrahedron-Asymmetr 2000, 11:1645-1680.

11. Arrieta JM, Herndl GJ: Assessing the diversity of marine bacterial betaglucosidases by capillary electrophoresis Zymography. Appl Environ Microb 2001, 67:4896-4900.

12. Zhang L, Rong A, Wang J, Sun N, Zhang S, Hu J, Kuai J: Exploring novel bioactive compounds from marine microbes. Curr Opin Microbiol 2005 8:276-281

13. Imada C, Okami Y: Characteristics of marine actinomycete isolated from a deep-sea sediment and production of $\beta$-glucosidase inhibitor. J Mar Biotechnol 1995, 2:109-113.

14. Pandey S, Sree A, Dash SS, Sethi DP: A novel method for screening beta-glucosidase inhibitors. BMC Microbiol 2013, 13:55. doi:10.1186/ 1471-2180-13-55.

15. Lam KS: Discovery of novel metabolites from marine actinomycetes. Curr Opin Microbiol 2006, 9:245-251.

16. Bull AT, Stach JE, Ward AC, Goodfellow M: Marine actinobacteria: perspectives, challenges, future directions. Antonie Van Leeuwenhoek 2005 87:65-79.

17. Haefner B: Drugs from the deep: marine natural products as drug candidates. Drug Discov Today 2003, 8:536-544.

18. Stütz AE (Ed): Iminosugars as glycosidase inhibitors: Nojirimycin and beyond. Weinheim: Wiley-VCH; 1999.

19. Lillelund $V H$, Jensen $H H$, Liang $X$, Bols M: Recent developments of transition-state analogue glycosidase inhibitors of non-natural product origin. Chem Rev 2002, 102:515-553.

20. Saitou N, Nei M: The neighbor-joining method: a new method for reconstructing phylogenetic trees. Mol Biol Evol 1987, 4:406-425.

21. Felsenstein J: Confidence limits on phylogenies: an approach using the bootstrap. Evolution 1985, 39:783-791.

22. Nei M, Kumar S: Molecular Evolution and Phylogenetics. New York: Oxford University Press; 2000.
23. Liu HJ, Tian $Y$, Zheng $T L$, Yan $C L$, Hong HS: Studies of glucosidase activities from surface sediments in mangrove swamp. J Exp Mar Biol Ecol 2008, 367:111-117.

24. Zeng X, Xiao X, Li D, Gu Q, Wang F: Isolation identification and screening of microorganisms for cytotoxic activities from deep sea sediments at different pacific stations. World J Microb Biot 2010, 26:2141-2150.

25. Essghaier B, Rouaissi M, Boudabous A, Jijakli H, Sadfi-Zouaoui N: Production and partial characterization of chitinase from a halotolerant Planococcus rifitoensis strain M2-26. World J Microb Biot 2010, 26:977-984.

26. Murugan S, Arnold D, Pongiya UD, Narayanan PM: Production of Xylanase from Arthrobacter sp. MTCC 6915 using saw dust as substrate under solid state fermentation. Enzyme Research 2011:7. doi:10.4061/2011/696942. Article ID 696942.

27. Riffel A, Brandelli A: Keratinolytic bacteria isolated from feather waste. Braz J Microbiol 2006, 37:395-399.

28. Meulenbeld GH, Hartmans S: Thioglucosidase activity from Sphingobacterium sp. strain OTG1. Appl Microbiol Biot 2001, 56:700-706.

29. Ojima T, Saburi W, Yamamoto T, Kudo T: Characterization of Halomonas sp. Strain $\mathrm{H} 11$ a-Glucosidase activated by monovalent cations and its application for efficient synthesis of a-D-Glucosylglycerol. App/ Environ Microb 2012, 78:1836-1845.

30. Bitzer J, Grosse T, Wang L, Lang S, Beil W, Zeeck A: New aminophenoxazinones from a marine Halomonas sp.: fermentation, structure elucidation, and biological activity. J Antibiot 2006, 59:86-92.

31. Saimmai A, Sobhon V, Maneerat S: Production of biosurfactant from a new and promising strain of Leucobacter komagatae 183. Ann Microbiol 2012, 62:392-402.

32. Halpern M, Shake' d T, Pukall R, Schumann P: Leucobacter chironomi sp. nov., a chromateresistant bacterium isolated from a chironomid egg mass. Int J Syst Evol Micr 2009, 59:665-670.

33. Proksch P, Edrada RA, Ebel R: Drugs from the seas - current status and microbiological implications. Appl Microbiol Biot 2002, 59:125-134.

34. Pitcher DJ, Saunders NA, Owen RJ: Rapid extraction of bacterial genomic DNA with guanidium thiocyanate. Lett Appl Microbiol 1989, 8:151-156.

35. Chun J, Lee JH, Jung Y, Kim M, Kim S, Kim BK, Lim YW: EzTaxon: a web-based tool for the identification of prokaryotes based on 16S ribosomal RNA gene sequences. Int J Syst Evol Micr 2007, 57:2259-2261.

36. Thompson JD, Gibson TJ, Plewniak F, Jeanmougin F, Higgins DG The CLUSTAL_X Windows interface: flexible strategies for multiple sequence alignment aided by quality analysis tools. Nucleic Acids Res 1997, 25:4876-4882

37. Tamura K, Peterson D, Peterson N, Stecher G, Nei M, Kumar S: MEGA5: Molecular Evolutionary Genetics Analysis using Maximum Likelihood Evolutionary Distance, and Maximum Parsimony Methods. Mol Biol Evol 2011, 28:2731-2739.

\section{doi:10.1186/1475-2859-12-35}

Cite this article as: Pandey et al:: Diversity of marine bacteria producing beta-glucosidase inhibitors. Microbial Cell Factories 2013 12:35.

\section{Submit your next manuscript to BioMed Central and take full advantage of:}

- Convenient online submission

- Thorough peer review

- No space constraints or color figure charges

- Immediate publication on acceptance

- Inclusion in PubMed, CAS, Scopus and Google Scholar

- Research which is freely available for redistribution 